\title{
Body iron and its distribution between haem and non-haem fractions in the suckling rat
}

\author{
By A. J. LESLIE* AND I. KALDOR \\ Department of Physiology, The University of Western Australia, \\ Nedlands, Western Australia, 6009 \\ (Received I January I97I - Accepted 20 April I97I)
}

\begin{abstract}
I. Total body iron and some of its subfractions, i.e. haem iron, non-haem iron and ferritin iron, as well as ferritin were measured in groups of newborn rats and of rats aged 4,15 and $24 \mathrm{~d}$.

2. Iron accumulated in the rats throughout suckling, with slightly more going into the haem than into the non-haem fraction.

3. Per unit body-weight, haem iron was maintained well throughout the study period but total body iron and non-haem iron were both significantly diminished at $15 \mathrm{~d}$.

4. Within the non-haem fraction, ferritin iron was severely diminished at both 15 and $24 \mathrm{~d}$, but the non-ferritin portion of non-haem iron was increased.

5. The results were interpreted in terms of the relationship between the growth of body mass and the supply of iron to the young animal.
\end{abstract}

During the suckling period total body iron increases in the rat from about $0.3 \mathrm{mg}$ at birth to $0.9 \mathrm{mg}$ at weaning (McCance \& Widdowson, 1951; Morgan, 196I) but during this period total body iron concentration falls, from $5 \mathrm{mg} / \mathrm{I} 00 \mathrm{~g}$ to less than $4 \mathrm{mg} / \mathrm{roO} \mathrm{g}$, as the growth of body mass exceeds the rate of iron accumulation. Manipulation of maternal iron metabolism, creating either iron-loaded or irondepleted mothers during pregnancy and lactation, does not appear to affect the iron status of the suckling young (Drabkin \& Fitz-Hugh, 1934; Bruner, van de Erve \& Carlson, 1938; Morgan, r96r). In the study reported here, total body iron, haem, non-haem and ferritin iron and ferritin were measured simultaneously in rats at birth and at 4,15 and $24 \mathrm{~d}$ post partum. A pattern of iron distribution in rats of these ages was established, which at no time approximated the pattern which characterizes the adult animal.

\section{EXPERIMENTAL}

\section{Animals}

Animals from a closed colony of Wistar rats, bred at the University of Western Australia Preclinical Animal House, were used. The diet consisted of a commercial pelleted mixture and water offered $a d l i b$. All litters were obtained from primiparous dams whose body-weights varied between 180 and $210 \mathrm{~g}$ at the time of littering. Chosen ages at sampling were newborn, 4,15 and $24 \mathrm{~d}$ post partum. These were selected as the result of a more comprehensive survey of developmental changes in liver storage iron (Leslie \& Kaldor, I97I) and represent the beginning and end of lactation and the ages at which liver storage iron concentrations are at their highest

* Present address: Department of Animal Science and Production, Institute of Agriculture, The University of Western Australia, Nedlands, Western Australia 6009. 
(4 d) and lowest ( $15 \mathrm{~d}$ ) over the suckling period. Only litters of between ten and twelve young were used and the ages at killing were within $6 \mathrm{~h}$ of the nominal age indicated. From each litter, pairs of animals were selected at random. The first pair was used for measuring total body iron and the second pair for total body haem iron, total body non-haem iron, total body ferritin and ferritin iron. The third and fourth pairs were used for a series of haematological measurements, the results of which will not be reported in this paper. The remaining animals in each litter were used as substitutes, as was necessary. Each determination was done on sixteen animals, two from each of eight litters at each sampling age.

In reporting the results the arithmetic difference between the measured quantities of non-haem iron and ferritin iron will be referred to as 'non-ferritin non-haem iron'.

The significance of the difference between the mean values for different age groups was tested statistically by Student's $t$ test.

\section{Collection of materials and analytical procedures}

After removal from the dam, animals were immediately killed with anaesthetic ether BP, weighed, washed by immersion in dilute hydrochloric acid for $30 \mathrm{~min}$ to remove extraneous iron-containing material from the skin and fur, rinsed in distilled water and stored frozen. For total body iron, whole animals were digested in two to three times their weight of concentrated sulphuric acid, perchloric acid $(70 \%, w / w)$ being added dropwise at the completion of the digestion until the solution had cleared. On cooling, the contents were transferred to volumetric flasks, made up to volume with deionized water and were assayed for iron (Kaldor, 1958).

For the estimation of haem iron, non-haem iron and ferritin iron and ferritin, whole animal carcasses were homogenized in a wet grinder with four to five times the tissue weight of deionized water. Replicate portions of the well-mixed homogenates produced in this way were used for each determination. Haem iron was estimated by an acid haematin method (Greenberg \& Erickson, 1944). A $5 \mathrm{ml}$ sample of the well-mixed distilled-water homogenate was transferred to a $25 \mathrm{ml}$ volumetric flask and $5 \mathrm{ml}$ of a mixture of equal volumes of $5 \%(\mathrm{v} / \mathrm{v})$ hydrochloric acid solution and of glacial acetic acid $(99.6 \%)$, and $\mathrm{I} 5 \mathrm{ml}$ of a one to four mixture of $90 \%(\mathrm{v} / \mathrm{v})$ ethanol and ether BP were added. The absorbance of the haem extracted into the ether phase was measured at $635 \mathrm{~nm}$ in stoppered glass cuvettes of $\mathrm{I} \mathrm{cm}$ path length, in a Unicam SP 600 spectrophotometer, calibrated with blood of known haem and iron content, extracted as acid haematin in the way described. Techniques previously described were used for measuring non-haem iron (Kaldor, 1958) and ferritin and ferritin iron (Leslie \& Kaldor, 1970), using duplicate samples of the distilled-water homogenate in each instance.

The skin and fur of furred animals ( 15 and $24 \mathrm{~d}$ old) were removed by dissection, digested separately in concentrated sulphuric acid and were assayed independently for iron as described for total body iron. This was necessary as it was not possible to homogenize skin and fur with the techniques used. This iron, which represented an average of 22 and $44 \mu \mathrm{g}$ respectively for the two age groups, was included as a correction, in the total non-haem iron fraction. 
During the time the suckling rat is consuming an exclusively milk diet, virtually all of the ingested iron is absorbed, whereas a decreasing fraction is absorbed as weaning begins (Ezekiel, 1967; Loh \& Kaldor, 1971). At $24 \mathrm{~d}$ post partum the proportion of ingested iron absorbed is only 20-30\% (Ezekiel, 1967; Loh \& Kaldor, 1971). To correct for the unabsorbed iron in $15^{-}$and 24 -d-old rats, the gastro-intestinal contents of each of eight animals from these age groups were flushed out with $0.9 \%$ sodium chloride solution, were acid-digested and assayed for iron as described above for total body iron. The average measured iron of this material was 25 and $190 \mu \mathrm{g}$ for $\mathrm{I}^{-}$- and 24-d-old rats respectively. These amounts were subtracted from the values obtained for total body iron and for the total body non-haem iron fractions.

\section{RESULTS}

Total body iron and its principal subfractions for the four age groups are shown in Fig. I. Total body iron increased sixfold from birth to $24 \mathrm{~d}$. Within this period $400 \mu \mathrm{g}$ iron were gained during the first $15 \mathrm{~d}$, and a further $600 \mu \mathrm{g}$ between 15 and $24 \mathrm{~d}$. Haem iron also increased about sixfold from birth to $24 \mathrm{~d}$ of age. The rate at which iron increased in this fraction was very similar to the rate of increase for total body iron: about threefold between birth and $\mathrm{I} 5 \mathrm{~d}$ post partum and approximately twofold in the next $9 \mathrm{~d}$. Non-haem iron only slightly more than doubled in the period from birth to $15 \mathrm{~d}$, but increased a further twofold over the next $9 \mathrm{~d}$.

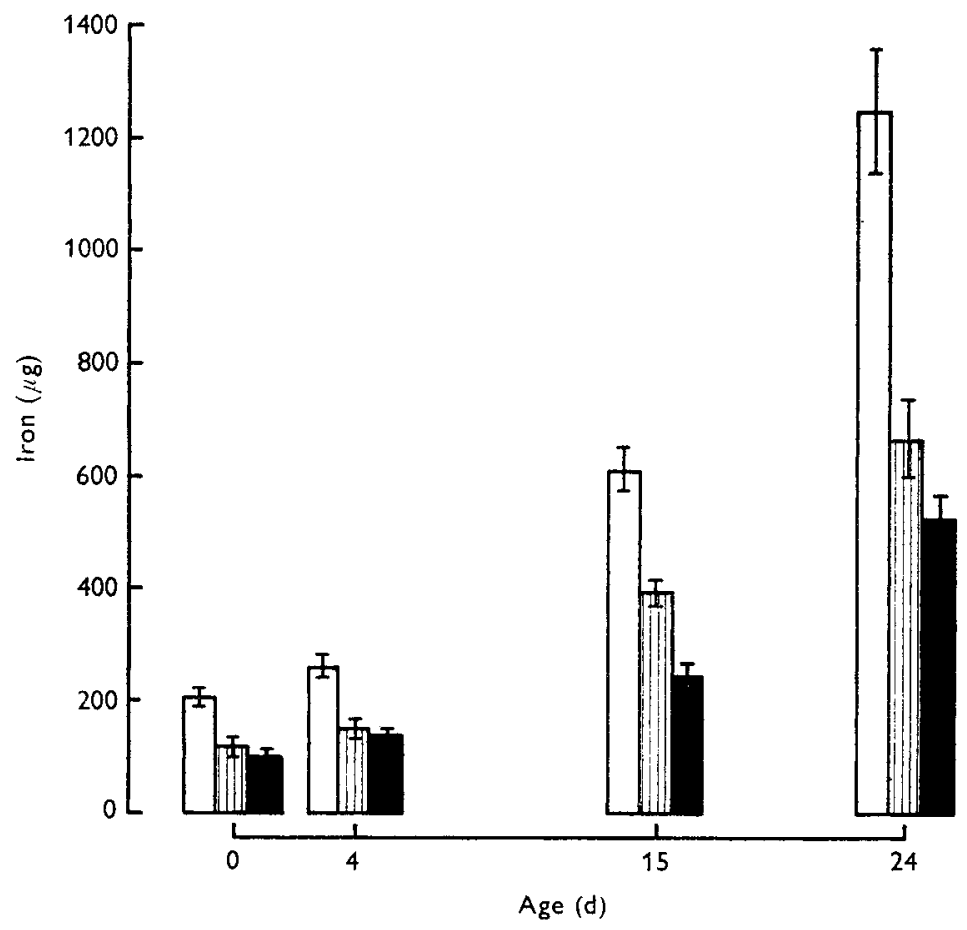

Fig. I. Total body iron ( $\square$ ), haem iron (四), and non-haem iron ( $\square$ ) per rat in suckling rats at four ages. The heights of the columns indicate the mean and the vertical bars indicate \pm I standard error. 
Fig. 2 shows the results for ferritin, ferritin iron and non-ferritin non-haem iron. By $4 \mathrm{~d}$ of age, ferritin iron had increased to be approximately $50 \%$ greater than the value at birth, but by $15 \mathrm{~d}$ of age iron had been removed and only $75 \%$ of the iron found in this fraction at birth remained. At $24 \mathrm{~d}$ there was twice as much ferritin iron as at birth. Non-ferritin non-haem iron increased approximately ninefold from birth to $24 \mathrm{~d}$ and, unlike ferritin iron, increased steadily (Fig. 2). Ferritin exhibited a similar pattern of change to ferritin iron, and by $24 \mathrm{~d}$ post partum it was about four times greater than at birth. The average iron content of ferritin decreased progressively through the period covered by the study, from a value of $21 \cdot 5 \%$ at birth to $\operatorname{Ir} \cdot 2 \%$ at $24 \mathrm{~d}$

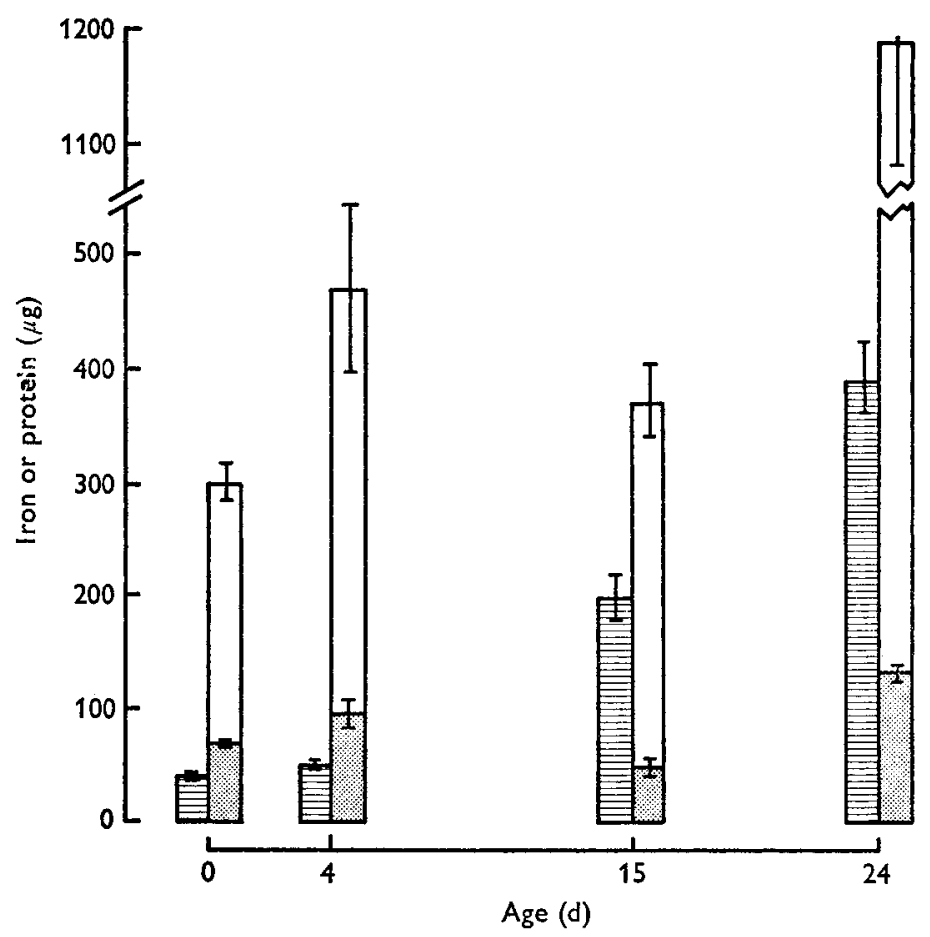

Fig. 2. Total body non-ferritin non-haem iron (目), ferritin iron (国), and ferritin (闻 plus $\square$ ) per rat in suckling rats at four ages. The heights of the columns indicate the mean and the vertical bars indicate \pm I standard error.

In Fig. 3 results for total body iron, haem and non-haem iron are shown expressed as a concentration ( $\mu \mathrm{g}$ iron/g wet body-weight). At $4 \mathrm{~d}$ all three measurements were the same as at birth, but by $15 \mathrm{~d}$ total body iron and non-haem iron concentrations had fallen to values lower than those at birth $(P<0.001)$. By $24 \mathrm{~d}$ total body iron and haem iron concentrations were the same as at birth, but non-haem iron concentration was still below the value at birth, although considerably greater than the value at $15 \mathrm{~d}$ $(P<0.01)$.

In Fig. 4, ferritin, ferritin iron and non-ferritin non-haem iron concentrations $(\mu \mathrm{g} / \mathrm{g}$ wet body-weight) for the four age groups are shown. Like total non-haem iron 


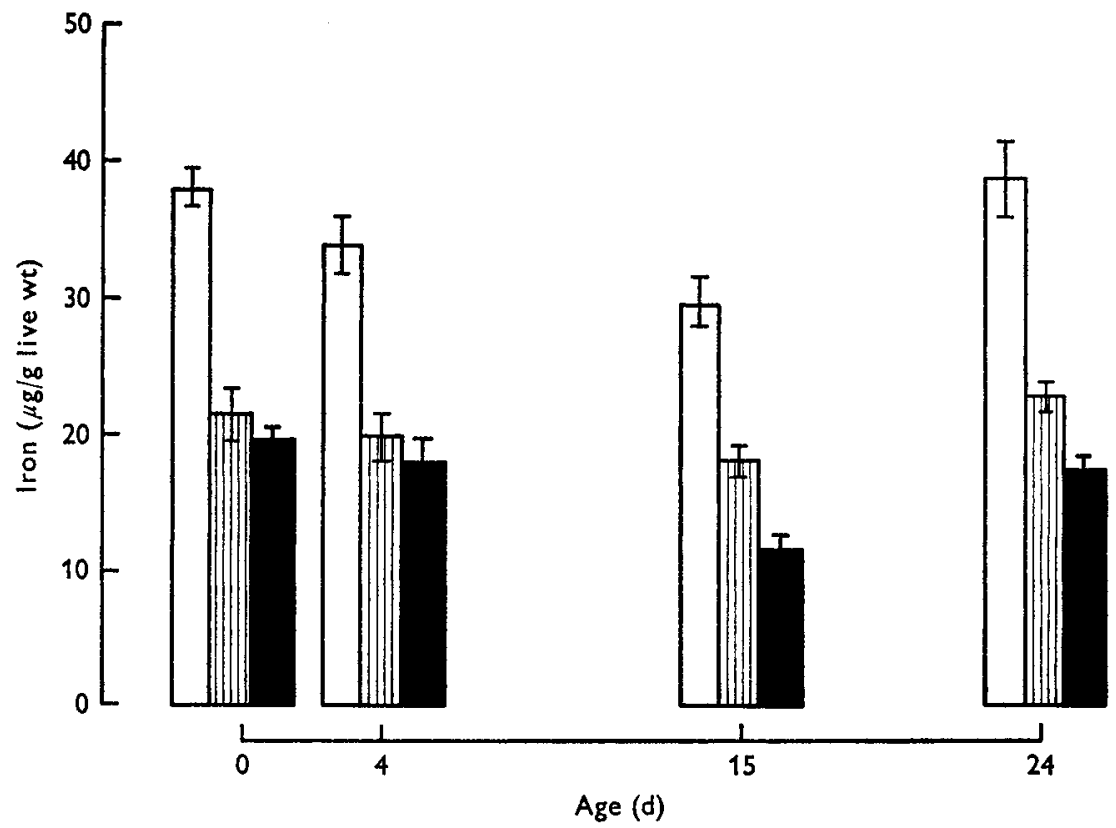

Fig. 3. Concentration of total body iron ( $\square$ ), haem iron (四), and non-haem iron ( $\square$ ) in suckling rats at four ages. The heights of the columns indicate the mean and the vertical bars indicate $\pm \mathrm{I}$ standard error.

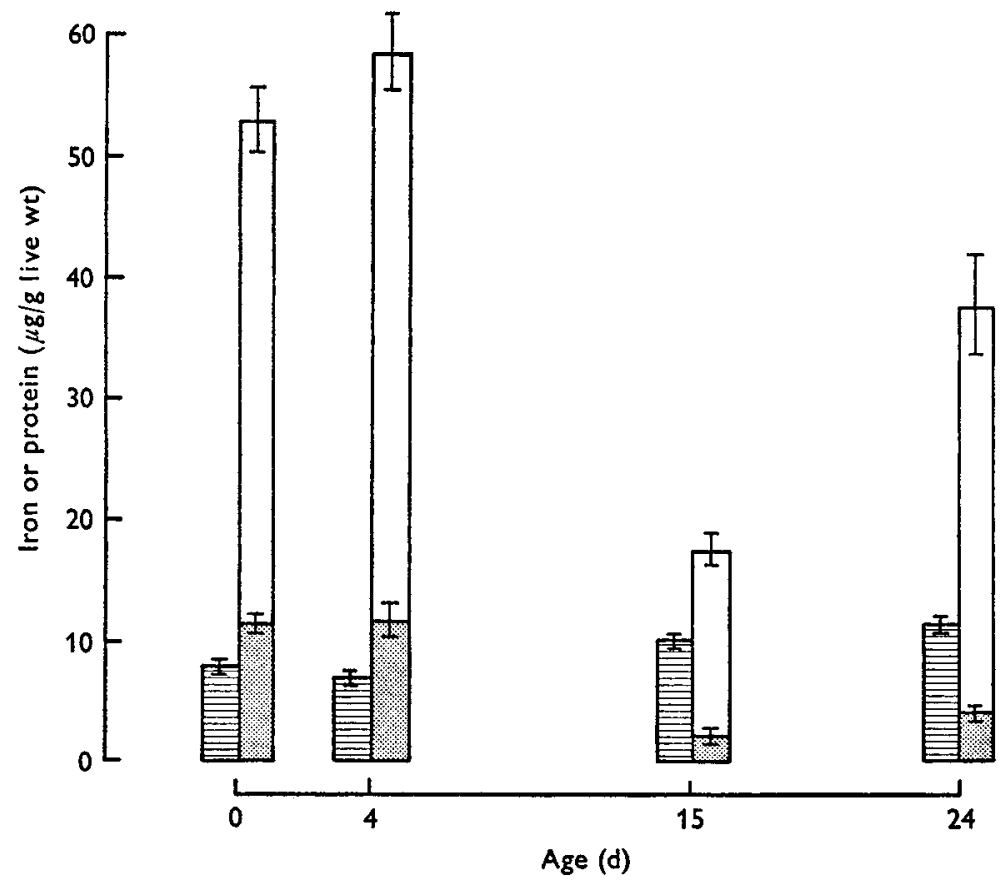

Fig. 4. Concentration of non-ferritin non-haem iron (目), ferritin iron (国), and ferritin (葘 plus $\square$ ) in groups of suckling rats at four ages. The heights of the column indicate the mean and the vertical bars indicate $\pm I$ standard error. 
concentration, ferritin and ferritin iron concentrations were depressed below the birth values at both $\mathrm{I} 5$ and $24 \mathrm{~d}(P<0.00 \mathrm{I}$ for both). However, non-ferritin non-haem iron concentration increased over the period of observation, and at $24 \mathrm{~d}$ was signifcantly greater $(P<0.001)$ than at birth.

\section{DISCUSSION}

The period covered by this study falls into two distinct sections. During the first, from birth to $15 \mathrm{~d}$, the suckling rats' nutritional needs are met exclusively from the maternal milk supply. From around i $5 \mathrm{~d}$ physiological weaning begins; the young rats gradually consume an increasing amount of solid food, and a rapidly increasing proportion of their nutritional requirements comes from this source. In the colony used in this study, litters are normally removed from the lactating dam between 24 and $27 \mathrm{~d}$ of age; however, animals aged $\mathrm{I} 8 \mathrm{~d}$ or more can survive and thrive if removed from the dam (Loh \& Kaldor, 1971).

Iron was accumulating continuously in the growing animals' bodies through the period studied. The total body iron increment was threefold between birth and $\mathrm{I}_{5} \mathrm{~d}$ and twofold between 15 and $24 \mathrm{~d}$ (Fig. I). There was no significant difference in body iron concentration between newborn, 4-d-old and 24-d-old rats; however, the body iron concentration of $x_{5}$-d-old animals was significantly lower (Fig. 3 ). The results imply that by the end of the 2nd week of life milk as the sole dietary source of iron had become inadequate in maintaining the iron status of the animal at the level at birth. This is in keeping with the results of other studies (Huggett \& Widdas, 1949; Spray \& Widdowson, I950; Morgan, 196r). Recovery occurred rapidly after $15 \mathrm{~d}$, as mixed feeding became established.

At $15 \mathrm{~d}$ the non-haem iron concentration was reduced to only a little more than half the value at birth (Fig. 3). The reduction in the ferritin portion of the non-haem iron fraction was even more severe, ferritin iron falling to one-quarter of that at birth. In contrast to this, the concentration of iron in the non-ferritin portion of the non-haem fraction was increased at $15 \mathrm{~d}$ over the values at birth or those at $4 \mathrm{~d}$ (Fig. 4). This non-ferritin non-haem iron was the only fraction which had increased significantly $(P<0.001)$ over the entire $24 \mathrm{~d}$ period studied. The form and location of this iron has not been established and its identity is conjectural. The transferrin iron of plasma and 'transitional iron' - representing either iron involved in erythropoiesis, just before insertion into the haemoglobin molecule of red cell precursors, or iron in reticuloendothelial cells from newly catabolized red cells - must form a small part of the non-ferritin non-haem fraction. To this may be added iron in the form of 'haemosiderin' in liver, spleen, bone marrow and other locations. As implied by an earlier study (Leslie \& Kaldor, 197I), the amounts of iron in this form are also unlikely to be large. It is possible that some of the unidentified iron was in muscle and other tissues as 'parenchyma iron', as described in several studies (Torrance, Charlton, Schmaman, Lynch \& Bothwell, 1968; Hahn \& Whipple, 1936; Mazur \& Shorr, 1950; Hallgren, I954). Whatever the form and location of this iron, its accumulation took precedence over that of all other forms of iron through the suckling period, and at the time of 
weaning it represented about three-quarters of the non-haem iron fraction. Closer identification of this iron will be necessary before a full balance-sheet of the developmental changes in the newborn animals can be drawn up.

The variations in the concentration of ferritin were not unlike those of ferritin iron concentration during the study period (Fig. 4). However, the ferritin changed less markedly than its iron and, as a consequence, the average percentage iron concentration fell from $2 \mathrm{I}^{\cdot} 5$ at birth to $\mathrm{II} \cdot 2$ at $24 \mathrm{~d}$. Thus, in contrast with the newborn and the mature animal, the distribution of ferritin molecules between unfilled (apoferritin) and fully iron-filled was shifted in the 4-d-old and particularly in the 15-d-old and 24-d-old animals towards a higher proportion of the less fully filled molecules. This was in keeping with earlier findings on livers and spleens of suckling rats (Leslie \& Kaldor, I971) and represents a pattern never reported in normal adult animals.

In the interval between birth and $4 \mathrm{~d}$, about $60 \mu \mathrm{g}$ iron accumulated in the body of the individual pup. This corresponds to $600 \mu \mathrm{g}$ for a litter of ten young, the standard litter size used in this study. In the period $4^{-1} 5 \mathrm{~d}$, each individual increased its total body iron by about a further $340 \mu \mathrm{g}$, i.e. $3400 \mu \mathrm{g}$ for a whole litter. There was thus a total increase per litter for the first $15 \mathrm{~d}$ of postnatal life of around $4 \mathrm{mg}$ iron, all of which had come from the milk. Together with the $2 \mathrm{mg}$ iron per litter of ten young, which existed at birth and had been obtained by placental transfer, the total iron contribution of a mother to her ten young from conception to the 15 th day of lactation was around $6 \mathrm{mg}$. The further contribution of maternal milk to the increase in total body iron of the young cannot be estimated here. However, this is likely to be small as the concentration of iron in the solid food presented was thirty to forty times greater than the concentration of iron in the milk.

The authors wish to acknowledge the technical assistance of Miss L. R. Witherow. This work was supported by grants from the National Health and Medical Research Council, Commonwealth of Australia, and by the University of Western Australia Medical Research Grants Fund.

\section{REFERENCES}

Bruner, H. D., van de Erve, J. \& Carlson, A. J. (1938). Am. F. Physiol. r24, 620.

Drabkin, D. L. \& Fitz-Hugh, T. Jr (1934). Am. F. Physiol. 108, 61.

Ezekiel, E. (1967). F. Lab. clin. Med. 70, 138.

Greenberg, A. \& Erickson, D. (1944). F. biol. Chem. 156, 679.

Hahn, P. F. \& Whipple, G. H. (1936). Am. F. med. Sci. 191, 24.

Hallgren, B. (1954). Acta Soc. Med. upsalien. 59, 79.

Huggett, A. St G. \& Widdas, W. F. (1949). F. Physiol., Lond. 110, 386.

Kaldor, I. (1958). Aust. F. exp. Biol. med. Sci. 36, 173.

Leslie, A. J. \& Kaldor, I. (1970). Analyt. Biochem. 37, 64.

Leslie, A. J. \& Kaldor, I. (197I). Am. F. Physiol. 220, 1000.

Loh, T. T. \& Kaldor, I. (1971). Biol. Neonate 17, 173.

McCance, R. A. \& Widdowson, E. M. (195I). F. Physiol., Lond. 112, 450.

Mazur, A. \& Shorr, E. (1950). F. biol. Chem. 182, 607.

Morgan, E. H. (1961). F. Physiol., Lond. ז58, 573.

Spray, C. M. \& Widdowson, E. M. (1950). Br. F. Nutr. 4, 332.

Torrance, J. D., Charlton, R. W., Schmaman, A., Lynch, S. R. \& Bothwell, T. H. (1968). F. clin. Path. 2r, 495 . 